\title{
White-Tailed Deer Densities and Brush Cover on the Rio Grande Plain
}

\author{
ALLEN A. STEUTER AND HENRY A. WRIGHT
}

\begin{abstract}
Rio Grande Plain habitats with a range in total brush cover from 10 to $97 \%$ were selected from three brush control treatments and native brush types. Deer density in each habitat was determined from helicopter census and observation towers. Three brush cover classes resulted in three levels of white-tailed deer use during summer. Areas with less than $43 \%$ total brush cover had a maximum density of 1.4 deer $/ 40.5 \mathrm{ha}$. Brush cover from 43 to $60 \% \mathrm{had}$ a maximum density of 3.25 deer $/ \mathbf{4 0 . 5}$ ha. Highest summer deer use occurred on areas with 60 to $97 \%$ total brush cover $(7.5 \mathrm{deer} / 40.5$ ha).
\end{abstract}

The association of white-tailed deer (Odocoileus virginianus) with brush habitats is a subject of considerable interest to Texas range managers. The Rio Grande Plain has extensive areas of dense mixed brush vegetation (Davis and Spicer 1965) and some of the highest deer densities in the United States.

Mechanical, chemical, and prescribed burning methods have been used to reduce brush cover, thereby increasing forage production and livestock handling efficiency. Often this is accomplished at the expense of deer habitat (Box 1964). At the same time, ranchers have discovered the income potential of selling hunting rights on their land (Teer and Forrest 1968). Only recently has the attempt been made to evaluate the economic returns from livestock and whitetailed deer which result from brush control treatments (Whitson et al. 1977).

Herbicidal brush control applied in strips that treat $80 \%$ of a pasture have little effect on deer numbers; however, $100 \%$ block spraying, which removes $86 \%$ of the woody canopy, has been shown to reduce deer numbers for as long as a year (Beasom and Scifres 1977). Herbicide treatments, that removed $75 \%$ of the living brush canopy, had no effect on "screening cover" at deer height (Tanner et al. 1978).

Brush functions as an important source of both food and cover for white-tailed deer in South Texas (Davis 1952, McMahan 1964, McMahan and Inglis 1974). Since brush provides part or all of two major components of deer habitat, the intensity of deer use on an area may be related to brush cover or distribution. The purpose of this study was to determine the relationship between deer density and various levels of brush cover in native brush habitats and brush control areas, which had not been commercially hunted since 1948.

\section{Study Areas and Methods}

The study was conducted on the Piloncillo Ranch, $6.4 \mathrm{~km}$ south of Catarina, Texas (Fig. 1). The ranch lies in the west-central

The authors are research assistant and Horn professor, Department of Range and Wildlife Management, Texas Tech University, Lubbock 79409. This research was supported in part by U.S.D.A. Forest Service, Rocky Mountain Forest and Range Experiment Station, Southern Great Plains Wildlife Habitat Laboratory, and is published as Texas Tech University, College of Agricultural Sciences Publication No. T-9-216. Wc thank Dan Harrison, Jr., who let us conduct this study on his ranch. Manuscript received May 14, 1979. portion of the Rio Grande Plain vegetation zone as described by Correll and Johnston (1970). Approximately 40 species of woody plants are present in the area which Muller (1947) termed "thorn scrub." Mesquite (Prosopis glandulosa var. glandulosa) is well represented on all sites. However, blackbrush (Acacia rigidula), whitebrush (Aloysia lycioides), twisted acacia (Acacia tortuosa), lotebush (Ziziphus obtusifolia), guayacan (Porlieria angustifolia), squawbush (Condalia spathulata), Texas colubrina (Colubrina texensis), guajillo (Acacia berlandieri), and pricklypear (Opuntia lindheimeri) can also assume a dominant or co-dominant position, depending on local conditions.

Primary soil associations are Brundage, Maverick, Pryor (Aridisols), and Duval and Brystal (Alfisols). Study areas included a mixture of Hardland, Rolling Hardland, and Gray Sandy Loam (CN, CS, HN, HS), mixtures of Hardland, Clay Loam, and Sandy Loam (SN, SS), Sandy Loam (PN, PS), and Clay Loam (BN, BS, LN, LS) range sites (unpublished, Dimmit Co. soil survey). Soil textures varied from sandy loam to clay.

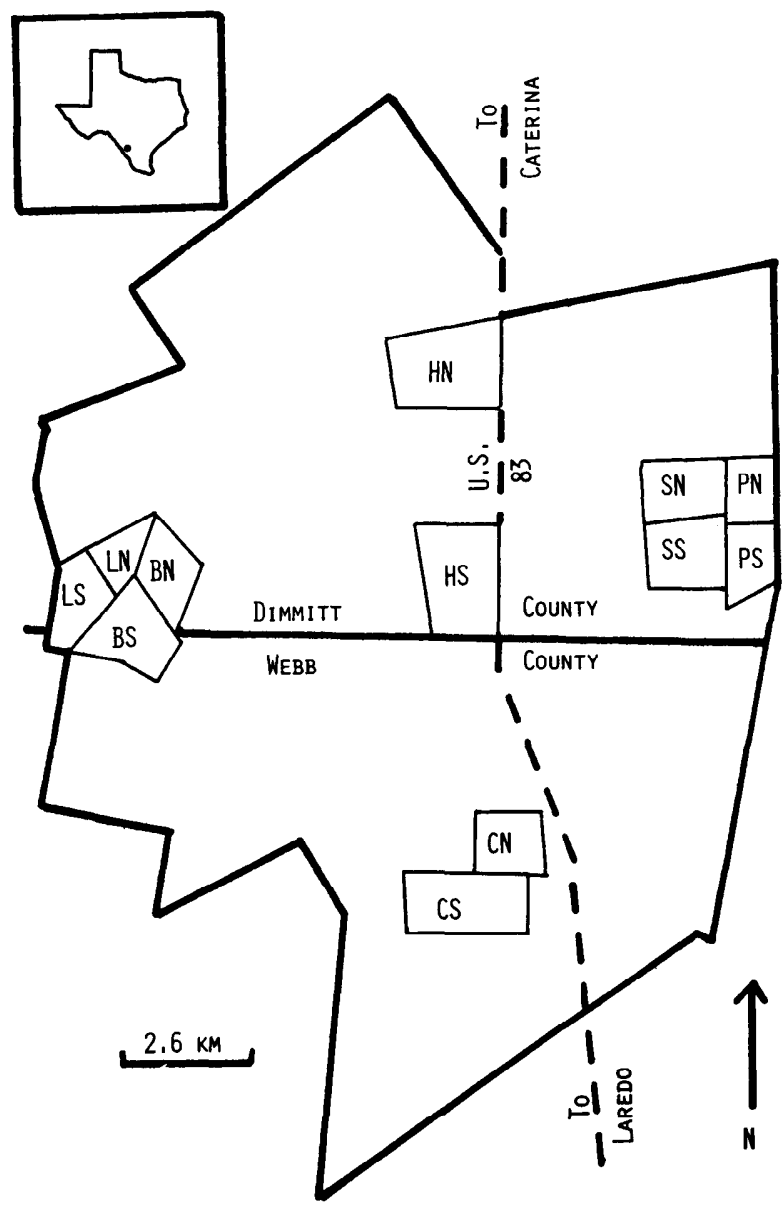

Fig. 1. Geographical location of Piloncillo Ranch in Texas (insert) and distribution of study areas on the western half of the Pilocillo Ranch: PN, $P S=$ controls; $S N, S S=$ sprayed treatments; $C N, C S=$ controls; $H N$, $H S=$ rootplowed treatments; $L N, L S=$ controls; $B N, B S=$ sprayed and burned treatments. 
The study was conducted from May 1977 through July 1978. Research was conducted on 12 study areas of 90 to 365 ha (Fig. 1). Study areas were selected to encompass wide variation in brush cover between areas and minimal variation within study areas. Total shrub cover ranged from 10 to $97 \%$ and grass cover varied from 4 to $110 \%$. Bare ground ranged from 0 to $37 \%$. Sampling within study areas was confined to permanent 20.3-ha circular study sites. Thirty study sites were used.

Study areas SN and SS (Fig. 1) were aerial sprayed with Tordon 225 (1: 1, 2,4,5-T and Picloram) in June 1975 at $0.56 \mathrm{~kg} /$ ha. Study areas BN and BS were sprayed with Tordon 225 in June 1975 and burned in February 1976. Study areas HN and HS were rootplowed in 1956. The remaining six study areas (PN, PS, CN, CS, $\mathrm{LN}, \mathrm{LS})$ received no brush control treatment.

Helicopter censuses by study area were conducted from 7:00 to 9:00 a.m. in Ja nuary and July 1978 to determine deer density. Also, continuous 2-hr counts were made from the center of study sites using portable hunting towers $5.2 \mathrm{~m}$ tall. Four tower counts were logged at each study site during June, July, and August and two counts were logged on 18 selected sites during November 1977 and January 1978. Tower counts were conducted either from sunrise plus $2 \mathrm{hr}$, or sunset minus $2 \mathrm{hr}$. The timing of helicopter and tower counts corresponded to the daily peaks in deer activity (Michael 1970, Montgomery 1963).

Variability in brush cover around towers resulted in a wide range of distances at which deer could be seen. Data were analyzed on deer-per-hectare-visible basis to account for this variation in visible distance. The visible area around each tower site was mapped on grid paper by two observers before deer counts were made. The number of visible hectares was determined with a planimeter. Area estimates of the two observers were usually within $10 \%$ of the mean. The visible area was defined as that area in which an active unalarmed deer could be seen at some time while moving through the site.

Brush and grass cover was recorded by species using three 30.5-m line intercepts per study site. The dead standing brush in the sprayed and burned areas added to the screening cover. Therefore, both living and dead brush were used in relating cover to deer use. Cover values for the study areas were obtained by taking the average of the study sites within an area. The horizontal distribution of screening cover on study sites was described using a vegeta-

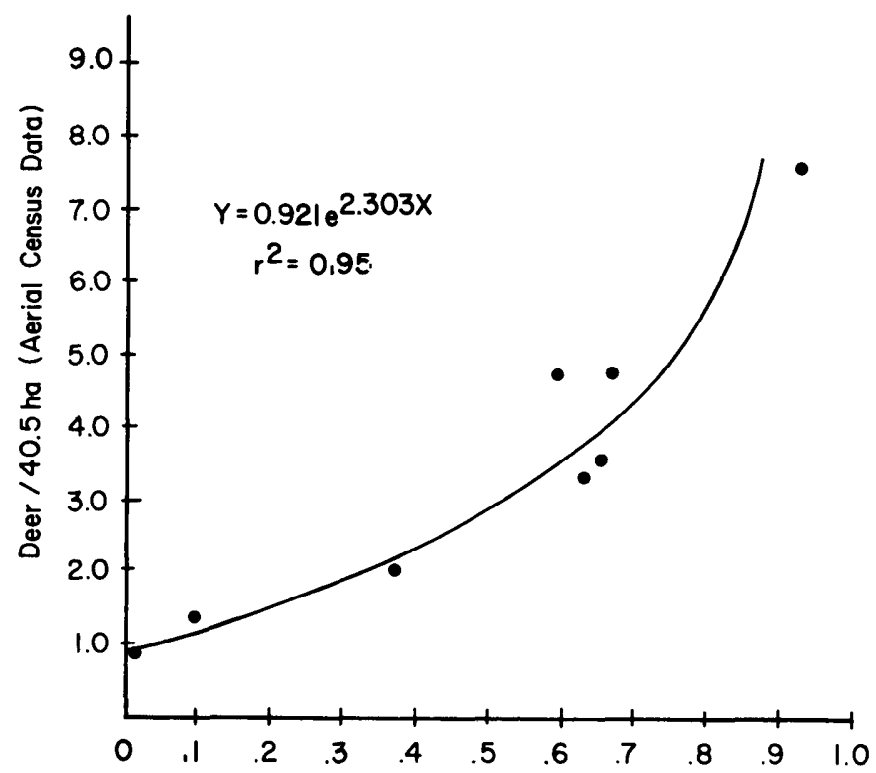

Deer Observed/.405 ha (Tower Data - 2 hr Obsn.)

Fig. 2. Relationship between deer density determined from aerial census and deer activity determined from tower ohservations for eight study areas. Tower data are the average of two study sites per study area. tion profile board (Nudds 1977). This data provided a measure of cover stratification due to differences in canopy height and density. Herbaceous composition was determined from a minimum of 33 , $0.25-\mathrm{m}^{2}$ frequency plots per study site.

\section{Results and Discussion}

Cover of shrubs was a good predictor of habitat preference for white-tailed deer in summer. As brush cover decreased, white-tailed deer numbers declined (Fig. 3 and 4). No apparent relationship existed between shrub cover and deer use during November and January. Composition of shrubs, grasses, and forbs was not correlated to habitat preference of white-tailed deer, although when shrub cover was below $50 \%$, a large variety of shrub species seemed more desirable than less diverse brush stands.

\section{White-tailed Deer Census}

Most data collected on white-tailed deer were obtained from systematic observations from towers on 30 study sites. To evaluate whether these data were a measure of deer density or deer activity, data taken from towers were compared to aerial census data for the eight study areas sampled during the summer 1978. The average density of deer on the study sites, within a study area, and the density obtained by aerial census were highly correlated $(P<0.01)$ (Fig. 2). This correlation indicated that tower data could be used validly to estimate deer density on study sites, assuming that helicopter censuses were unbiased and accurate.

\section{Deer Density and Brush Cover}

Both aerial censuses and tower counts of six study areas during November and January indicated no differential deer use of habitats with a range in brush cover from 15 to $75 \%$. Deer appeared to be uniformly distributed across the available brush types.

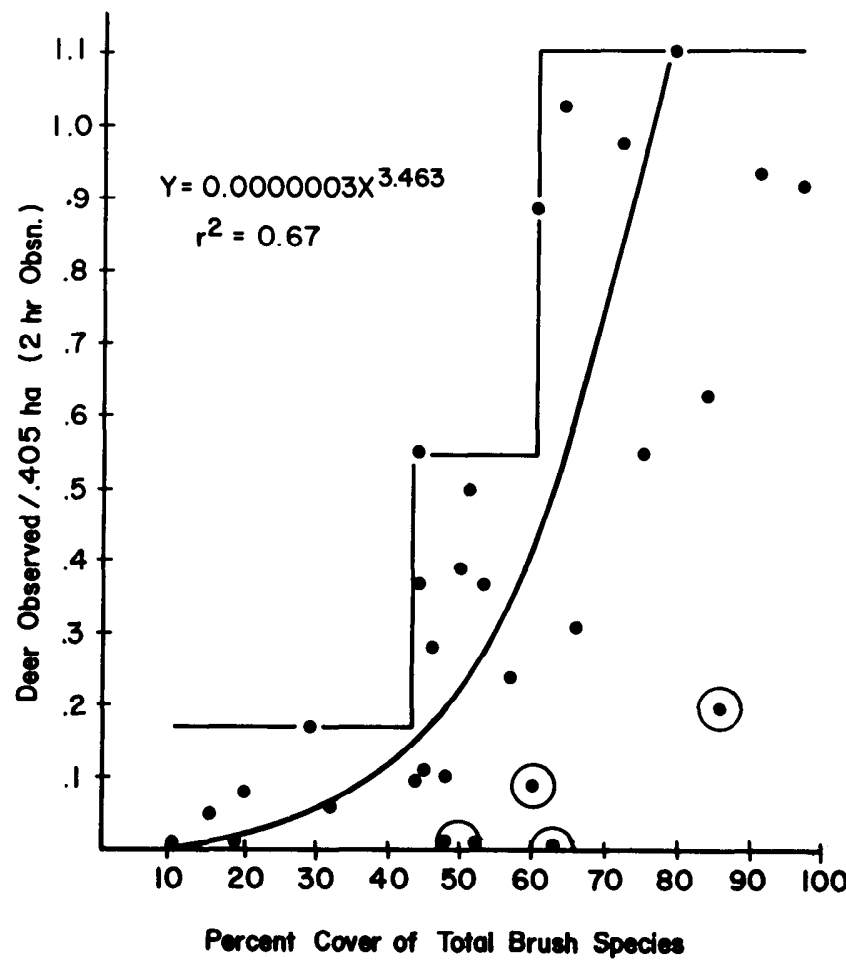

Fig. 3. Relationship between the number of deer observed per 0.405 ha from towers and percent cover of total brush species for 30 study sites during the summer. Deer data are the average of four, 2-hr observations. Circled sites not included in regression. 
Tower observations suggested that deer spent a large portion of the early morning and evening hours involved in rut activities. Bucks associated with does were a common sight during this season, whereas bucks and does were segregated during the summer and spent most of their active time feeding. Michael (1965) reported that bucks and, to a lesser extent does, tended to have larger home ranges during the winter. The preoccupation with mating and increased mobility of deer made it difficult to determine their response to habitats of varying brush cover.

Summer deer activity on 25 study sites was positively correlated $(P<0.01)$ with total brush cover in the range of 10 to $97 \%$ (Fig. 3). Similarly, aerial census of summer densities for the 12 study areas showed a positive correlation $(P<0.01)$ with brush cover (Fig. 4).

Total brush cover of $43 \%$ and $60 \%$ seemed to be critical levels for white-tailed deer summer habitat (Fig. 3). Below $43 \%$ cover, deer use was low, with a maximum density of 1.4 deer $/ 40.5$ ha. Total brush cover from 43 to $60 \%$ resulted in a maximum of 3.25 deer $/ 40.5$ ha. Total brush cover from 43 to $60 \%$ resulted in a maximum of 3.25 deer $/ 40.5$ ha. The highest deer use, during the summer, occurred on sites with 60 to $97 \%$ total brush cover. On these sites the maximum density exceeded 7.5 deer $/ 40.5$ ha. The maximum densities were projected using the model in Figure 2. Variability below the maximum line was probably due to site features other than cover which made some sites less suitable for deer.

Some inferences might be drawn from five sites, apparently unsuitable for white-tailed deer and excluded from the regression model (Fig. 3). Sites B6 and C5 had total brush cover of 60 and $63 \%$, respectively; however, the horizontal vegetation density on these sites was relatively low. The vegetation profile indicated that height of most cover was above $1.5 \mathrm{~m}$ on $\mathrm{C} 5$ and below $1.0 \mathrm{~m}$ on B6. Study sites $\mathrm{S} 2$ and S5 were dense whitebrush bottoms. Site L1 was a dense mesquite type ( $86 \%$ cover) with less than $5 \%$ herbaceous cover in the understory. All five of these sites were substantially under used by deer relative to other sites in the same cover class (Fig. 3).

Good summer deer habitat had total brush cover about

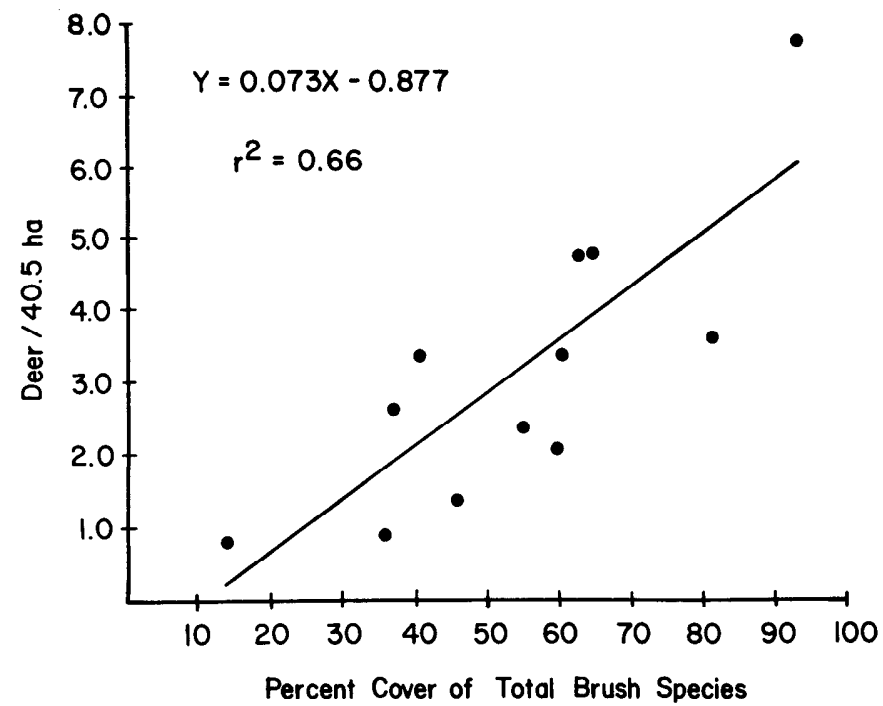

Fig. 4. Relationship between deer density determined from aerial census and percent cover of total brush species for 12 study areas during the summer.
$60 \%$. Mixed brush types which resulted in understory shrub growth also characterized these sites.

The minimum grass cover for sites receiving highest deer use was $10 \%$. Forb composition and frequency varied greatly between sites and years; however, no consistent relationship could be determined with deer use of an area. Although forbs are a preferred food item, browse is the staple in deer diets on the Rio Grande Plain (Davis and Winkler 1968). Therefore, sites with a wide selection of browse species may provide a more nutritious food supply. No relationship was apparent between brush diversity and deer use on sites with more than $51 \%$ total brush cover. Sites with less than $50 \%$ brush cover tended to receive heavier deer use if brush composition was more diverse.

On untreated study sites the brush cover and composition were broadly determined by range site. Range sites with lowest deer use were hardland and rolling hardland; however, two of these range sites, characterized by a diverse brush composition and grass cover greater than 55\%, had high deer use. Deer use of clay loam range sites varied from low to high, whereas sandy loam range sites had moderate to high deer use. McMahan and Inglis (1974) also noted that deer were attracted to sandy loam range sites.

Neither brush composition nor range site differences adequately explained the variability in deer use of sites with approximately equal brush cover. Deer use of sites below the maximum levels observed for the three broad cover classes $(0-43 \%, 43-60 \%, 60-97 \%)$, was apparently due to habitat factors not measured during this study.

The study areas were relatively large blocks of low, medium, and high brush cover. Deer use on smaller areas of low brush cover may be substantially different than reported here. Davis and Winkler (1968) suggested that an interspersion of small openings in dense brush habitats may be advisable for deer.

\section{Conclusions}

The results of this study can be used to define more accurately the trade-offs between white-tailed deer and livestock production in the Rio Grande Plain. Maintenance of a given deer density requires that adquate habitat be available on a year-round basis. Total brush cover accounted for $67 \%$ of the variability in deer density as measured by two census methods during the summer months. At this time of year brush appears to be an important source of both cover and food. Brush control practices are obviously directed at altering this habitat component and the ranch manager should be aware that decreases in brush cover over large areas will result in lower deer use.

\section{Literature Cited}

Beasom, S.L., and C.J. Scifres. 1977. Population reaction of selected game species to aerial herbicide applications in South Texas. J. Range Manage. 30: 138-142.

Box, T.W. 1964. Changes in wildlife habitat composition following brush control practices. in South Texas. Trans. N. Amer. Wildl. Conf. 29: 432-438.

Correl, D.S., and M.C. Johnston. 1970. Manual of vascular plants of Texas. Texas Research Foundation. Renner, Texas. 1881 p.

Davis, R.B. 1952. The use of rumen contents data in a study of deer-cattle competition and "animal equivalence." Trans. N. Amer. Wildl. Conf. 17: 448-458.

Davis, R.B., and R.L. Spicer. 1965. Status of the practice of brush control in the Rio Grande Plain. Texas Parks and Wildlife Bull. No. 46. 40 p. 
Davis, R.B., and C.K. Winkler. 1968. Brush vs cleared range as deer habitat in South Texas. J. Wildl. Manage. 32: 321-329.

McMahan, C.A. 1964. Comparative food habits of deer and three classes of livestock. J. Wildl. Manage. 28: 798-808.

McMahan, C.A., and J.M. Inglis. 1974. Use of Rio Grande Plain brush types by white-tailed deer. J. Range Manage. 27: 369-374.

Michael, E.D. 1965. Movements of white-tailed deer on the Welder Wildlife Refuge. J. Wildl. Manage. 29: 44-52.

Michael, E.D. 1970. Activity patterns of white-tailed deer in South Texas. Texas J. Sci. 21: 417-428.

Montgomery, G.G. 1963. Nocturnal movements and activity rhythms of white-tailed deer. J. Wildl. Manage. 27: 422-427.
Muller, C.H. 1947. Vegetation and climate of Coahuila, Mexico. Madrono $9: 33-57$.

Nudds, T.D. 1977. Quantifying the vegetative structure of wildlife cover. Wild. Soc. Bull. 5: 113-117.

Tanner, G.W., J.M. Inglis, and L.H. Blankenship. 1978. Acute impact of herbicide strip treatment on mixed brush white-tailed deer habitat on the Northern Rio Grande Plain. J. Range Manage. 31: 386-391.

Teer, J.G., and N.K. Forrest. 1968. Bionomic and ethical implication of commercial game harvest programs. Trans. N. Am. Wildl. Conf. 33: 192-204.

Whitson, R.E., S.L. Beasom, and C.J. Scifres. 1977. Economic evaluation of cattle and white-tailed deer response to aerial spraying of mixed brush. J. Range Manage. 30: 214-217. 